\title{
JOB INSECURITY: MEDIATOR OR MODERATOR OF THE RELATIONSHIP BETWEEN TYPE OF CONTRACT AND VARIOUS OUTCOMES? ${ }^{1}$
}

\author{
NELE DE CUYPER \\ HANS DE WITTE \\ Nele.decuyper@psy.kuleuven.be \\ Research Group Stress, Health and Well-being \\ K.U. Leuven, Belgium
}

\begin{abstract}
Research on the consequences of job insecurity among temporary workers has been largely exploratory. This study investigates whether job insecurity either mediates or moderates the relationship between type of contract (temporary versus permanent) and its outcomes. It extends previous research by including a wide range of outcomes (job satisfaction, engagement, organisational commitment, trust, general health, irritation, turnover intention, performance, and positive work life interference), most of which have not yet been considered in this context. Results $(\mathrm{N}=656)$ point to the moderating role of job insecurity, however only for outcomes reflecting immediate reactions. Implications for future research are discussed.
\end{abstract}

\section{OPSOMMING}

Navorsing oor die gevolge van werksonsekerheid onder tydelike werknemers was tot dusver hoofsaaklik eksploratief. Hierdie studie ondersoek of werksonsekerheid die verhouding tussen kontraktipe (tydelik teenoor permanent) en uitkomste medieer of modereer. Dit bou op vorige navorsing deur 'n wye verskeidenheid uitkomste (werkstevredenheid, begeestering, organisasieverbondenheid, vertroue, algemene gesondheid, irritasie, arbeidsverloop intensie, prestasie en positiewe lewensuitkyk), die meeste waarvan nog nie tot op hede in hierdie konteks inaggeneem is nie. Resultate $(\mathrm{N}=656)$ dui op werksonsekerheid se modererende rol, alhoewel slegs vir uitkomste wat onmiddelike reaksies tot gevolg hê. Implikasies vir toekomstige navorsing word bespreek.

Within the literature exploring its determinants, the formal employment contract has been identified as perhaps one of the most critical factors affecting job insecurity (Kinnunen \& Nätti, 1994; Näswall \& De Witte, 2003; Sverke, Gallagher \& Hellgren, 2000). More specifically, job insecurity is exacerbated in temporary employment arrangements (Parker, Griffin, Sprigg \& Wall, 2002). This goes to the extent that job insecurity has been suggested to reflect the subjective counterpart of temporary employment (Büssing, 1999; Klandermans \& Van Vuuren, 1999). The many observations on the harmful effects of job insecurity (De Witte, 1999; Sverke, Hellgren \& Näswall, 2002) have resulted in the suggestion of impaired well-being, and less desirable attitudes and behaviors among temporary as compared to permanent workers (Beard \& Edwards, 1995). That is, job insecurity is assumed to mediate, i.e. to account for (Baron \& Kenny, 1986), the relationship between temporary employment and its outcomes: job insecurity is considered to be 'hidden beneath' type of contract (De Witte \& Näswall, 2003). Little empirical effort has been made to validate this assumption. There are however strong arguments to do so.

First, studies failed to establish a conclusive link between type of contract and a diverse range of outcomes (Casey \& Allach, 2004; Connelly \& Gallagher, 2004), which is however conditional for mediation (Baron \& Kenny, 1986). For example, most studies found temporaries to be less satisfied with their job as compared to permanents (Benach, Gimeno $\&$ Benavides, 2002; OECD, 2002). Other studies did not establish significant contract-based differences on job satisfaction (De Witte \& Näswall, 2003); still others found temporaries to score higher on job satisfaction than permanents (Galup, Saunders, Nelson \& Cerveny, 1997; Guest \& Conway, 1997; McDonald \& Makin, 2000). Similarly, inconclusive results have been observed with regard to organisational commitment (De Witte \& Näswall, 2003; Pearce, 1993; Van Breukelen \& Allegro, 2000). Temporary

Requests for copies should be addressed to: $N$ De Cuyper,

nele.decuyper@psy.kuleuven.be employment has not been extensively examined from the perspective of psychological and physical health (Connelly \& Gallagher, 2004), with the notable exceptions of several Scandinavian studies (for an overview, see De Cuyper, Isaksson \& De Witte, 2005) and the European Surveys on Working Conditions (Benavides, Benach, Diez-Roux \& Roman, 2000). Results on health until now have been contradictory. For example, Aronsson, Gustafsson and Dallner (2002), as well as Sverke, Gallagher and Hellgren (2000) found general indicators of well-being to produce little if any contract-based differences, while permanents reported more stress and more mental health problems than temporaries in both the Second and Third European Survey on Working Conditions (Paoli \& Merllié, 2002). Finally, clear-cut differences between permanents and temporaries are absent when studying behaviours, such as performance (Van Breukelen \& Allegro, 2000). In case of inconsistent relationships between predictor and criterion variables, as is the case for temporary employment and its psychological outcomes, a moderator rather than mediator variable is typically introduced (Baron \& Kenny, 1986).

Second, predictions on how job insecurity affects temporaries have been made based on samples largely dominated by permanents, or on samples that excluded temporaries from the analyses (Virtanen, Vahtera, Kivimäki, Pentii \& Ferrie, 2002). However, anecdotic evidence suggests that the harmful effects of job insecurity do not hold for temporaries. That is, job insecurity has been found problematic for permanents but not for temporaries in terms of job satisfaction and organisational commitment in the studies by De Witte and Näswall (2003), and by Guest and Conway (2000). Similarly, Virtanen, Vahtera, Kivimäki, Pentii and Ferrie (2002) as well as Sverke, Gallagher and Hellgren (2000) observed a stronger negative relationship between high levels of job insecurity and health among permanents as compared to temporaries. This suggests that job insecurity might moderate rather than mediate the relationship between type of contract and outcomes. 
In response to these observations, this paper aims to assess the position of job insecurity among employees differing in type of contract. The study addresses the question whether job insecurity either mediates or moderates the relationship between type of contract and outcomes. More specifically, we investigate whether job insecurity accounts for the relationship between type of contract and a set of outcomes, or otherwise changes this relationship in strength or direction. The study extends previous research by broadening the range of outcomes to include job satisfaction, engagement, positive work-home interference, organisational commitment, trust, general health, irritation (stress), performance, and turnover intention. These outcomes cover the four major categories of potential outcomes of job insecurity, as identified by Sverke, Hellgren and Näswall (2002; Figure 1): the quadrants distinguish immediate from long-term reactions, and individual versus organisational outcomes.

\begin{tabular}{|l|l|l|}
\hline & Individual & Organizational \\
\hline Immediate & $\begin{array}{l}\text { Job attitudes } \\
\text { e.g., job satisfaction } \\
\text { e.g., engagement } \\
\text { e.g., positive work-home } \\
\text { interference }\end{array}$ & $\begin{array}{l}\text { Organisational attitudes } \\
\text { e.g., } \text { organisational } \\
\text { commitment } \\
\text { e.g., trust }\end{array}$ \\
\hline Long term & $\begin{array}{l}\text { Health \& Well-being } \\
\text { e.g., irritation } \\
\text { e.g., health }\end{array}$ & $\begin{array}{l}\text { Work-related behaviour } \\
\text { e.g., performance } \\
\text { e.g., turnover intention }\end{array}$ \\
\hline
\end{tabular}

Figure 1: The outcomes of job insecurity (Sverke, Hellgren \& Näswall, 2002)

\section{RESEARCH DESIGN}

\section{Data Collection}

The survey data were collected during the first six months of 2004 , totaling 656 respondents. Employees were sampled in two target sectors, the industrial $(\mathrm{N}=354)$ and the retail $(\mathrm{N}=$ 302) sector with 6 and 7 organisations respectively. Response rates exceeded $50 \%$ in all industrial organisations, with the exception of one organisation $(13 \%)$. In the retail sector, response rates fluctuated between $33 \%$ and $60 \%$. One retail organisation had a lower response $(20 \%)$. The choice for these organisations was made on the basis of expected variation in employment contracts.

\section{Respondents}

Almost one out of three respondents (32,3\%; $\mathrm{N}=212$ ) was employed temporarily, the vast majority $(94,3 \%)$ of which had a fixed term contract. Fixed term contracts are defined in line with the OECD (Organisation for Economic Co-operation and Development, 2002) as contracts that are brought to termination by objective conditions, for example the completion of an assignment, or the return of an employee who has been temporarily replaced. The remainder of the temporary sample $(5,7 \%)$ was employed by an agency. These workers were asked to fill out questions taking the organisation they performed work at as a reference.

The sample was dominated by blue-collar workers $(\mathrm{N}=388$; $62,8 \%)$ rather than white-collar workers $(\mathrm{N}=203 ; 37,2 \%)$, and by women $(\mathrm{N}=393 ; 61,0 \%)$ rather than men $(\mathrm{N}=251$; $39,0 \%)$. Fifteen percent of the respondents went to college (higher education or university). On average, respondents spent 12 years in fulltime education. The respondents were rather young, with an average age of 35 years: $38,4 \%$ of the sample was aged 30 or below, $29,6 \%$ was aged between 31 and 40 , and $24,2 \%$ was aged between 41 and 50 . The oldest group included $7,8 \%$ of the respondents.
Furthermore, most respondents did not work on night shifts $(\mathrm{N}=518 ; 79,8 \%)$, and did not work part-time, defined as less than 33 hours per week $(\mathrm{N}=397 ; 61,7 \%)$. Finally, $12,5 \%$ or 80 respondents were single or lived as a single, while $85,4 \%(\mathrm{~N}=560)$ were married or cohabiting, or lived with their family or parents.

In line with population trends, the temporary sample was younger $(\mathrm{M}=30$ years $)$ than the permanent sample $(\mathrm{M}=37$ years; $\mathrm{t}(653)=-9,55, \mathrm{p}<0,01)$, and more temporaries $(18 \%)$ than permanents $(10 \%)$ reported to be single $\left(\chi^{2}(1, \mathrm{~N}=\right.$ $640)=8,08, p<0,01)$. Also, temporaries reported less working hours $(\mathrm{M}=28$ hours $/$ week $)$ as compared to permanents $(\mathrm{M}=34, \mathrm{t}(641)=-7,43, \mathrm{p}<0,01)$. Furthermore, $28 \%$ of the temporary sample compared to $16 \%$ of the permanent sample worked on night shifts $(t(647)=3,45$, $\mathrm{p}<0,01)$. Finally, $70 \%$ of the temporary sample compared to $57 \%$ of the permanent sample was female, $\chi^{2}(1, \mathrm{~N}=644)=$ $9,36, p<0,01$. No contract-based differences were found for occupational status (blue collar versus white collar, $\chi^{2}(1, N=618)=0,03$, n.s. $)$ or years spent in fulltime education $(\mathrm{t}(653)=0,60$, n.s. $)$.

\section{Measures}

All scales reported in this section were found to have single factor structures (PCA, Varimax). Response scales ranged from 1 (strongly disagree) to 5 (strongly agree), unless stated otherwise.

\section{Control Variables}

In order to rule out alternative explanations, important individual and work-related factors were controlled for. Age, average working hours per week, and years spent in fulltime education were measured as continuous variables. Occupational position $(0=$ blue collar worker; $1=$ white collar worker $)$, working in night shifts $(0=$ no; $1=$ yes $)$, family status $(0=$ single; $1=$ married/cohabiting/living with family or parents), and gender $(0=$ female; 1 = male) were dummy-coded. Finally, the sector in which the respondents were employed was added as control variable, with 0 representing the industrial sector, and 1 the retail sector.

\section{Independent Variable}

Type of contract was dichotomised as permanent (0) versus temporary (1) contracts.

\section{Intervening Variable}

Job insecurity was measured with four items constructed by De Witte (2000). This scale had a reliability of 0,86 , and included both cognitive (e.g., 'I am sure I can keep my job'; reverse coded), and affective items (e.g., I feel insecure about the future of my job'). This scale has been used previously (see e.g., Sverke, Hellgren, Näswall, Chirumbolo, De Witte \& Goslinga, 2004), and proved useful in explaining variance in, for example, organisational commitment and job satisfaction.

\section{Dependent Variables}

Job satisfaction was measured with four items developed by Price (1997). A sample item is 'I am not happy with my job' (reverse coded). Reliability was high $(\alpha=0,82)$.

The dimensions 'vigor' and 'dedication' of the Utrecht Work Engagement Scale (Schaufeli \& Bakker, 2003) were used to tap Engagement. This scale included ten items (e.g., 'I am enthusiastic about my job'), with responses varying from 1 (never) to 6 (always). Reliability was high $(\alpha=0,95)$.

Positive work-home interference was measured using four items of the Survey Work-home Interaction Nijmegen (SWING) of Geurts (2000). Respondents had to indicate how often $(1=$ rarely or never; $5=$ very often or always $)$ it happened that they for example 'come home cheerfully after 
a successful day at work, positively affecting the atmosphere at home' $(\alpha=0,82)$.

Four items were used to tap organisational commitment (Cook \& Wall, 1980). The item 'I am quite proud to be able to tell people who it is I work for' acts as an example $(\alpha=0,69)$.

Trust was a seven-item scale, adapted from the scale as reported by Isaksson et al. (2002), and Rigotti et al. (2003). The scale focused upon trust in the organisation, its managers, and organisational practices. Sample items are 'to what extent do you trust your immediate line manager to look after your best interests?', or 'Do you feel you are fairly treated by managers and supervisors?'. Responses could vary from 1 (not at all) to 5 (totally). Reliability is high $(\alpha=0,89)$.

Health was measured with the subscale 'general health' of the SF12 questionnaire (Ware, 1999). A sample item is 'My health is excellent'. Respondents indicated the extent to which they agreed with each of the five items, with responses varying from 1 (definitely false) to 5 (definitely true). Reliability equals 0,77 .

Irritation was measured using four items developed by Mohr and Rigotti (2003; Rigotti et al., 2003). The scale describes subjective emotional and cognitive strain. It reflects an early stage of psychological impairment with items as 'I get irritated easily, even when I don't want to' or 'From time to time I feel like a bundle of nerves'. Responses could vary from 1 (strongly disagree) to 7 (strongly agree) $(\alpha=0,85)$.

Turnover intention was measured using four items (e.g., 'I would be reluctant to leave this job', reverse coded) of Price (1997) $(\alpha=0,79)$

Performance was measured on a scale from 1 (very badly) to 5 (very well), relying on the items of Abramis (1994). Respondents rated their qualitative performance on nine work-related aspects), for example with regard to making decisions, or taking initiatives $(\alpha=0,78)$.

Information about means, standard deviations, and correlations between scales is to be found in table 1 .

Hypotheses were tested using regression analyses, applying list wise deletion with slightly smaller samples as a consequence. Regressions were performed separately for all dependent variables.
Mediation Test

Figure 2 presents the mediation model. The hypothesis that job insecurity mediates the relation between type of contract (independent variable) and the outcomes (dependent variables) was tested by regressing (1) job insecurity on type of contract, (2) the outcomes on type of contract, and (3) the outcomes on both type of contract and job insecurity. This follows the procedure for mediation that is described by Baron \& Kenny (1986). Conditional for mediation is (1) that temporary employment predicts job insecurity, (2) that type of contract predicts the outcomes (temporary as compared to permanent employment yields less desirable results), and (3) that job insecurity affects the outcomes in the third regression equation (job insecurity yields detrimental results). If these conditions all hold in the predicted direction, then the third regression equation should show type of contract to have a smaller (partial mediation) or non-significant (full mediation) effect on the outcomes than in the second regression equation.

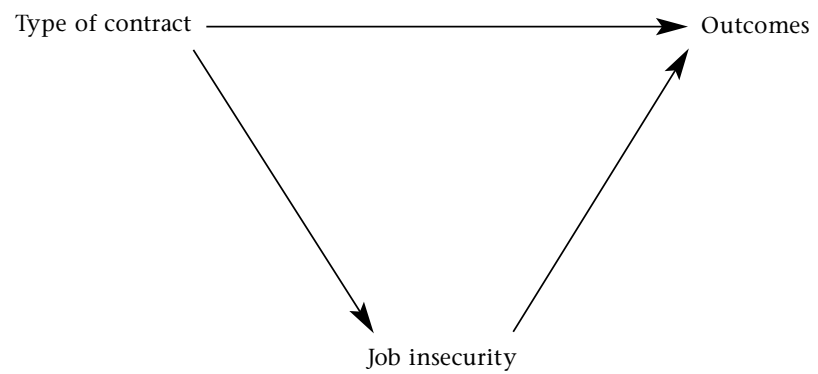

Figure 2: The mediational model

\section{Moderation Test}

Figure 3 presents the moderation model. The hypothesis that job insecurity moderates the relationship between type of contract and outcomes was tested following the procedure recommended by Aiken and West (1991): the control variables were entered in the first step of the regression equation, type of contract in the second, and job insecurity in the third. In the final step, the interaction term was added, with this interaction being a multiplication of the standardised variables. When

TABLe 1

The CORRELATION MATRIX

\begin{tabular}{|c|c|c|c|c|c|c|c|c|c|c|c|c|}
\hline & Mean & SD & 1 & 2 & 3 & 4 & 5 & 6 & 7 & 8 & 9 & 10 \\
\hline Type of contract ${ }^{1}$ & 0,32 & 0,47 & 1 & & & & & & & & & \\
\hline Job insecurity & 2,45 & 0,87 & $0,34^{* *}$ & 1 & & & & & & & & \\
\hline Job satisfaction & 3,99 & 0,67 & $0,15^{* *}$ & $-0,22^{* *}$ & 1 & & & & & & & \\
\hline Engagement & 3,76 & 1,09 & $0,12 * *$ & $-0,20^{* *}$ & 0,68 ** & 1 & & & & & & \\
\hline Work-home interference & 3,08 & 0,79 & 0,04 & $-0,12^{* *}$ & 0,41 ** & $0,44^{* *}$ & 1 & & & & & \\
\hline Org. commitment & 3,79 & 0,59 & $0,09^{*}$ & $-0,32^{* *}$ & $0,69^{* *}$ & $0,67^{* *}$ & $0,34^{* *}$ & 1 & & & & \\
\hline Trust & 3,32 & 0,85 & $0,18 * *$ & $-0,16^{* *}$ & $0,56^{* *}$ & 0,48 ** & $0,60^{* *}$ & $0,27^{* *}$ & 1 & & & \\
\hline General health & 3,82 & 0,69 & 0,07 & $-0,11^{* *}$ & 0,27 * * & 0,29 ** & 0,22 * * & $0,24^{* *}$ & $0,27^{* *}$ & 1 & & \\
\hline Irritation & 2,84 & 1,18 & $-0,17^{* *}$ & $0,14^{* *}$ & $-0,36^{* *}$ & $-0,29^{* *}$ & $-0,28 * *$ & $-0,36^{* *}$ & $-0,36^{* *}$ & $-0,14^{* *}$ & 1 & \\
\hline Turnover intention & 1,75 & 0,68 & $-0,11$ ** & 0,17 ** & $-0,71$ ** & $-0,54^{* *}$ & $-0,60^{* *}$ & $-0,48^{* *}$ & $-0,48^{* *}$ & 0,28 ** & $-0,30^{* *}$ & 1 \\
\hline Performance & 4,09 & 0,44 & $-0,07$ & $-0,19^{* *}$ & $0,29^{* *}$ & 0,42 ** & $0,34^{* *}$ & $0,16^{* *}$ & $0,16^{* *}$ & $-0,14^{* *}$ & $-0,25^{* *}$ & $0,23^{* *}$ \\
\hline
\end{tabular}

${ }^{1} 0=$ permanent; 1 = temporary

${ }^{*} \mathrm{p}<0,05 ;{ }^{* *} \mathrm{p}<0,01$ 
interactions proved significant, regression analyses with job insecurity predicting the outcomes after controlling for the background variables were performed separately for temporaries and permanents.

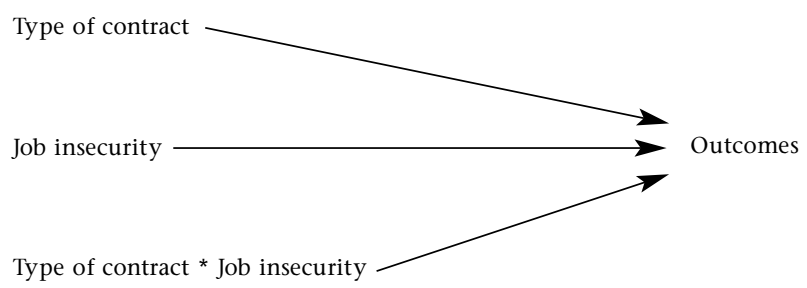

Figure 3: The moderation model

\section{RESULTS}

\section{Mediation}

Type of contract was highly predictive for job insecurity ( $\beta=$ $0,36, \mathrm{p}<0,01)$ : temporaries $(\mathrm{M}=2,88)$ were higher on job insecurity as compared to permanents $(M=2,25)$. This aligns with the first condition for mediation.

Furthermore, job insecurity was negatively related to job satisfaction $(B=-0,31, p<0,01)$, engagement $(B=-0,30, p<0.01)$, positive work-home interference $(B=-.11, \mathrm{p}<0.05)$, organisational commitment $(\beta=-0,40, p<0,01)$, trust $(B=-0,29$, $p<0,01)$, health $(B=-0,20, p<0,01)$, and performance $(B=-0,24$, $p<0,01)$. It was positively related to irritation $(B=0,29, p<0,01)$ and turnover intention $(B=0,27, p<0,01)$.

However, the effects of type of contract were either nonsignificant or opposite to those expected, based on the effects of job insecurity. More specifically, type of contract did not add significantly in explaining variance in general health $(B=$ 0,07 , n.s), performance ( $\beta=-0,06$, n.s.), and positive workhome interference $(B=0,07$, n.s. $)$. Also, temporary employment related positively to job satisfaction $(\beta=0,16$, p $<0,01)$, engagement $(B=0,20, p<0,01)$, organisational commitment $(B=0,13, p<0,01)$, and trust $(B=0,18, p<0,01)$. It related negatively to irritation $(B=-0,17, p<0,01)$, and turnover intention $(B=-0,15, p<0,01)$. This is illustrated in Table 2, in which the mean scores for both groups are presented. For general health, performance and positive work-home interference, the highly overlapping confidence intervals suggested that the null hypothesis of no contractbased differences might be likely. Altogether, evidence on job insecurity as a mediator between type of contract and the outcomes was lacking: the regression of outcomes on type of contract yielded results that are incompatible with the prediction of mediation by job insecurity.

The interaction term between type of contract and job insecurity proved significant for all outcomes reflecting the immediate consequences of job insecurity: job satisfaction, engagement, positive work-home interference, organisational commitment, and trust (Table 3). No such interaction was found for outcomes reflecting long-term reactions (general health, irritation, and performance), with the exception of turnover intention (Table 4).

A next step was to investigate the direction of the interaction effect. Table 5 suggests that job insecurity might be more detrimental for permanents as compared to temporaries. More specifically, job insecurity was highly predictive for job satisfaction, turnover intention, and positive workhome interference among permanents; it was not among temporaries. Furthermore, job insecurity predicted engagement and trust at a 0,05 level among temporaries, but at a 0,01 level among permanents. Finally, job insecurity yielded highly significant effects among both temporaries and permanents on organisational commitment. Still, the mutually distinct confidence intervals suggested that the job insecurity effect is significantly stronger among permanents.

TABLE 2

MEANS, STANDARD DEVIATIONS, AND CONFIDENCE INTERVALS

\begin{tabular}{|c|c|c|c|c|c|}
\hline & & \multirow[t]{2}{*}{ M } & \multirow[t]{2}{*}{ SD } & \multicolumn{2}{|c|}{$\begin{array}{l}\text { 95\% Confidence } \\
\text { Interval }\end{array}$} \\
\hline & & & & $\begin{array}{l}\text { Lower } \\
\text { bound }\end{array}$ & $\begin{array}{l}\text { Upper } \\
\text { bound }\end{array}$ \\
\hline \multirow[t]{2}{*}{ Job satisfaction } & Permanent & 3,92 & 0,68 & 3,86 & 3,99 \\
\hline & Temporary & 4,12 & 0,64 & 4,05 & 4,22 \\
\hline \multirow[t]{2}{*}{ Engagement } & Permanent & 3,67 & 1,08 & 3,57 & 3,77 \\
\hline & Temporary & 3,93 & 1,12 & 3,81 & 4,10 \\
\hline \multirow[t]{2}{*}{ Work-home interference } & Permanent & 3,06 & 0,79 & 2,98 & 3,13 \\
\hline & Temporary & 3,12 & 0,79 & 3,02 & 3,24 \\
\hline \multirow[t]{2}{*}{ Org. Commitment } & Permanent & 3,87 & 0,61 & 3,70 & 3,80 \\
\hline & Temporary & 3,95 & 0,63 & 3,79 & 3,95 \\
\hline \multirow[t]{2}{*}{ Trust } & Permanent & 3,21 & 0,84 & 3,13 & 3,29 \\
\hline & Temporary & 3,54 & 0,85 & 3,43 & 3,67 \\
\hline \multirow[t]{2}{*}{ Health } & Permanent & 3,79 & 0,70 & 3,72 & 3,85 \\
\hline & Temporary & 3,89 & 0,66 & 3,80 & 3,98 \\
\hline \multirow[t]{2}{*}{ Irritation } & Permanent & 2,97 & 1,17 & 2,86 & 3,08 \\
\hline & Temporary & 2,54 & 1,15 & 2,39 & 2,70 \\
\hline \multirow[t]{2}{*}{ Turnover intention } & Permanent & 1,80 & 0,69 & 1,73 & 1,86 \\
\hline & Temporary & 1,65 & 0,67 & 1,55 & 1,73 \\
\hline \multirow[t]{2}{*}{ Performance } & Permanent & 4,11 & 0,43 & 4,07 & 4,15 \\
\hline & Temporary & 4,04 & 0,46 & 3,98 & 4,11 \\
\hline
\end{tabular}

TABLE 3

SUMMARY OF HIERARCHICAL REGRESSION ANALYSIS FOR JOB SATISFACTION, ENGAGEMENT, ORGANISATIONAL COMMITMENT, TRUST, AND POSITIVE WORK-HOME INTERFERENCE

\begin{tabular}{|c|c|c|c|c|c|c|}
\hline & & $\begin{array}{c}\text { Job } \\
\text { satisf. }\end{array}$ & $\begin{array}{l}\text { Engag. } \\
\text { Comm. }\end{array}$ & Org. & Trust & $\begin{array}{l}\text { Work } \\
\text { home }\end{array}$ \\
\hline \multirow[t]{8}{*}{ Step 1} & Sector (retail) & $-0,02$ & $0,11^{*}$ & $-0,03$ & 0,09 & 0,04 \\
\hline & Position (white collar) & 0,05 & $-0,01$ & 0,09 & 0,04 & 0,06 \\
\hline & Hours/week & 0,00 & $0,14^{* *}$ & 0,01 & 0,06 & $-0,02$ \\
\hline & Night shifts & 0,01 & 0,07 & 0,05 & $-0,02$ & 0,09 \\
\hline & Married/Cohabiting & 0,04 & $0,08^{*}$ & 0,02 & 0,09 & $-0,12$ * * \\
\hline & Sex (male) & $-0,10^{*}$ & $-0,01$ & 0,00 & $-0,12^{* *}$ & $0,09 *$ \\
\hline & Age & 0,03 & $0,17^{* *}$ & 0,07 & $0,09 *$ & 0,00 \\
\hline & Fulltime education & $-0,05$ & $-0,08$ & $-0,05$ & 0,00 & 0,10 * \\
\hline Step 2 & Contract type & $0,24^{* *}$ & 0,28 ** & 0,25 * * & $0,10^{*}$ & $-0,15$ * * \\
\hline Step 3 & Job insecurity & $-0,38^{* *}$ & $-0,35$ ** & $-0,45$ * * & $-0,15^{* *}$ & $-0,11^{*}$ \\
\hline Step 4 & Interaction & $-0,26$ * * & $-0,19 * *$ & $-0,17$ * * & $-0,11$ * & 0,06 \\
\hline \multicolumn{2}{|l|}{$\mathrm{R}^{2}$ adj } & 0,17 & 0,17 & 0,17 & 0,12 & 0,06 \\
\hline \multicolumn{2}{|c|}{$\mathrm{R}^{2}$ change step 1} & $0,04^{* *}$ & $0,06^{* *}$ & $0,03^{*}$ & 0,03 & 0,05 * * \\
\hline \multicolumn{2}{|c|}{$\mathrm{R}^{2}$ change step 2} & 0,02 ** & 0,03 * * & $0,02^{* *}$ & 0,03 * * & 0,00 \\
\hline \multicolumn{2}{|c|}{$\mathrm{R}^{2}$ change step 3} & 0,07 * * & 0,07 * * & 0,12 ** & 0,07 * * & 0,01 * \\
\hline \multicolumn{2}{|c|}{$\mathrm{R}^{2}$ change step 4} & 0,05 ** & 0,03 * * & 0,02 * * & 0,03 * * & 0,01 * \\
\hline
\end{tabular}

** $\mathrm{p}<0,01 ; * \mathrm{p}<0,05$ 
TABLE 4

SUMMARY OF HIERARCHICAL REGRESSION ANALYSIS FOR HEALTH, IRRITATION, TURNOVER INTENTION AND PERFORMANCE

\begin{tabular}{|c|c|c|c|c|c|}
\hline & & Health & Irritation & $\begin{array}{l}\text { Turnover } \\
\text { intention }\end{array}$ & $\begin{array}{c}\text { Perform } \\
\text { ance }\end{array}$ \\
\hline \multirow[t]{8}{*}{ Step 1} & Sector (retail) & $-0,02$ & 0,14 * & 0,09 & $0,16^{* *}$ \\
\hline & Position (white collar) & 0,02 & 0,08 & 0,00 & $-0,14$ * * \\
\hline & Hours/week & 0,07 & 0,08 & $-0,01$ & 0,09 \\
\hline & Night shifts & 0,07 & $-0,01$ & $-0,04$ & 0,13 ** \\
\hline & Married/Cohabiting & 0,01 & 0,04 & $-0,02$ & $-0,00$ \\
\hline & Sex (male) & $-0,09$ & 0,01 & 0,07 & $-0,04$ \\
\hline & Age & $-0,03$ & $-0,01$ & $-0,10^{*}$ & 0,17 * * \\
\hline & Fulltime education & 0,06 & $-0,01$ & 0,04 & $-0,02$ \\
\hline Step 2 & Contract type & $0,14^{* *}$ & $-0,27$ * * & $-0,21$ * * & 0,03 \\
\hline Step 3 & Job insecurity & $-0,23$ ** & 0,29 ** & $0,34^{* *}$ & $-0,23$ ** \\
\hline Step 4 & Interaction & $-0,08$ & 0,02 & 0,26 * * & 0,03 \\
\hline \multicolumn{2}{|l|}{$\mathrm{R}^{2}$ adj } & 0,06 & 0,09 & 0,13 & 0,09 \\
\hline \multicolumn{2}{|c|}{$\mathrm{R}^{2}$ change step 1} & 0,02 & 0,02 & 0,02 & $0,06^{* *}$ \\
\hline \multicolumn{2}{|c|}{$\mathrm{R}^{2}$ change step 2} & 0,01 & 0,02 ** & 0,02 * * & 0,00 \\
\hline \multicolumn{2}{|c|}{$\mathrm{R}^{2}$ change step 3} & 0,03 * * & $0,06^{* *}$ & 0,05 ** & 0,04 * * \\
\hline \multicolumn{2}{|c|}{$\mathrm{R}^{2}$ change step 4} & 0,01 & 0,00 & $0,06^{* *}$ & $0,00 * *$ \\
\hline
\end{tabular}

TABLE 5

STANDARDIZED BETA AND CONFIDENCE INTERVALS OF JOB INSECURITY, SEPARATELY FOR PERMANENTS AND TEMPORARIES

\begin{tabular}{|c|c|c|c|c|}
\hline & & $\mathbf{M}$ & $95 \%$ & $\begin{array}{l}\text { nnfidence } \\
\text { erval }\end{array}$ \\
\hline & & \multirow[t]{2}{*}{$\beta$} & \multicolumn{2}{|c|}{$\begin{array}{l}95 \% \text { Confidence } \\
\text { interval for B }\end{array}$} \\
\hline & & & $\begin{array}{l}\text { Lower } \\
\text { bound }\end{array}$ & $\begin{array}{l}\text { Upper } \\
\text { bound }\end{array}$ \\
\hline \multirow[t]{2}{*}{ Job satisfaction } & Permanent & $-0,44$ ** & $-0,49$ & $-0,32$ \\
\hline & Temporary & $-0,11$ & $-0,17$ & 0,03 \\
\hline \multirow[t]{2}{*}{ Engagement } & Permanent & $-0,40$ ** & $-0,71$ & $-0,43$ \\
\hline & Temporary & $-0,16^{*}$ & $-0,34$ & 0,00 \\
\hline Work-Home & Permanent & $-0,18$ * * & $-0,32$ & $-0,09$ \\
\hline interference & Temporary & 0,01 & $-0,12$ & 0,13 \\
\hline \multirow[t]{2}{*}{ Org. Commitment } & Permanent & $-0,46$ ** & $-0,45$ & $-0,29$ \\
\hline & Temporary & $-0,29$ * * & $-0,25$ & $-0,08$ \\
\hline \multirow[t]{2}{*}{ Trust } & Permanent & $-0,38$ ** & $-0,54$ & $-0,31$ \\
\hline & Temporary & $-0,17^{*}$ & $-0,28$ & $-0,01$ \\
\hline \multirow[t]{2}{*}{ Turnover intention } & Permanent & 0,43 * * & 0,31 & 0,50 \\
\hline & Temporary & 0,02 & $-0,10$ & 0,12 ** \\
\hline
\end{tabular}

${ }^{* *} \mathrm{p}<0,01 ;{ }^{*} \mathrm{p}<0,05$

\section{DISCUSSION}

This study investigated the position of job insecurity in the relation between type of contract (permanent versus temporary) and various outcomes. Theoretically, job insecurity is thought to mediate this relationship. In this view, job insecurity is considered to be a classic work stressor with harmful effects for all employees. As temporary employment is associated with job insecurity, this leads to the expectation of adverse results among temporary workers. Empirical studies, however, did not succeed in establishing firm relationships between type of contract and outcomes. Moreover, preliminary evidence with a limited subset of outcome variables suggests job insecurity to play a different role on the basis of type of contract, with its effects being most harmful to permanents. This may suggest that job insecurity is a moderator rather than a mediator.

This study expanded previous research on this topic by (1) providing a systematic test of both the mediator and the moderator hypothesis, and by (2) including a diverse range of outcomes along the quadrant built by the dimensions immediate versus long term, and individually versus organisationally oriented (Sverke, Hellgren \& Näswall, 2002): job satisfaction, engagement, positive work-home interference, organisational commitment, trust, general health, irritation, turnover intention, and performance. Except for job satisfaction, organisational commitment and general health, these outcomes have not been included previously in relation to the combined effect of temporary employment and job insecurity.

\section{Summary of Results}

Altogether, we did not find evidence suggesting that job insecurity mediates the relationship between type of contract and the outcomes. As in previous studies, type of contract was highly predictive for job insecurity. Similarly, job insecurity was associated with unfavourable attitudes and behaviours, and with poor health. Consequently, mediation would require temporary employment to have adverse effects, in line with the effects of job insecurity. However, its effects were non-significant for general health, performance and positive work-home interference, and they were in the opposite direction for job satisfaction, engagement, organisational commitment, trust, irritation, and turnover intention.

In contrast, there was evidence for a moderator effect of job insecurity, at least for outcomes covering immediate consequences (job satisfaction, engagement, organisational commitment, and trust), as well as for turnover intention. Job insecurity affected permanents more severely than temporaries. More specifically, job insecurity proved less problematic for temporaries as compared to permanents in terms of engagement, trust, and organisational commitment; it was not problematic for temporaries in terms of job satisfaction, turnover intention, and positive work-home interference, whereas it was for permanents. No such moderation was found for variables measuring health and well-being or behavior.

These observations may further the debate on job insecurity: we found evidence that job insecurity does not need to be problematic in terms of psychological outcomes. Temporary workers were found more insecure as compared to permanents. Still, job insecurity did not result in lower job satisfaction, higher turnover intention, and impaired positive work-home interference, whereas it did for permanents. Furthermore, job insecurity effects on engagement, trust and organisational commitment were weaker for temporaries as compared to permanents. No such moderation effects were found for most of the long-term consequences (health, irritation, and performance). The long-term nature of these variables may possibly explain the absence of interaction effects, as they do not fit the inherently short-term nature of temporary assignments. Altogether, type of contract might challenge the traditional consideration of job insecurity as a classic stressor harmful to all employees. Also, our results refute the assumption that type of contract and job insecurity reflect the objective respectively subjective interpretation of the same construct: their impact on various outcomes is different. 
Similarly, we found evidence that type of contract does not need to be problematic in terms of psychological outcomes. At the contrary, temporary employment was not predictive for general health, performance, and positive work-home interference. Based on the mean scores and their confidence intervals separately for the permanent and temporary group, it can be argued that possible contract-based differences are not meaningful. Furthermore, temporary employment was positively associated with job satisfaction, engagement, organisational commitment, and trust, whereas it was negatively related to irritation and turnover intention. These observations may have important implications for research on the impact of temporary employment. Most authors have warned against the detrimental impact of temporary employment, primarily based on its inferior job characteristics (e.g., Beard \& Edwards, 1995), most notably job insecurity. Our study suggests that temporary employment does not necessarily lead to outcomes inferior to those reported by permanents.

\section{Limitations}

There are some drawbacks in our study. First, even though the varied organisational contexts offer some good possibilities for generalising findings towards a large population, this study is limited with regard to the specific type of temporary worker. The sample was heavily dominated by fixed term contract workers, in line with its relatively high share in the Belgian labour market. Therefore, generalising these results to other countries with different labour markets, or generalising results to include for example temporary agency workers and day-to-day contractors might not be appropriate.

Second, the response rates for most organisations were rather high, exceeding 50\% for all industrial organisations except for one, and fluctuating between $33 \%$ and $60 \%$ for all retail organisations except for one. Still, the results may not be fully representative for the population.

Furthermore, previous studies (for a review, see e.g. Sverke, Hellgren \& Näswall, 2002) have outlined that job insecurity causes detrimental outcomes, in line with theoretical considerations. Our data are cross-sectional in nature, which hampers a causal interpretation. A longitudinal design is however difficult to establish: sampling temporary workers for a longitudinal study may lead to high percentages of nonresponses in follow-up studies, due to the short-term nature of their assignments.

Finally, our data rely on self-reports, which may increase the risk of common variance. However, this may not be a major concern when testing for interactions: common method effects are likely to attenuate rather than to strengthen interaction effects (Conway \& Briner, 2002). Furthermore, type of contract as the central variable in this study is descriptive in nature, which may at least partially counteract the threat of common variance.

\section{Suggestions for Future Research}

One future area of research might be to fully include the heterogeneity of the temporary workforce, including temporary agency workers and day-to-day contractors. A major thesis in literature suggests that the mixed observations on the effect of type of contract stem from the variety of temporary employment arrangements (e.g., Connelly \& Gallagher, 2004). Accordingly, job insecurity may yield different effects, in terms of their size or their direction, depending on the specific type of temporary employment arrangement.

Furthermore, we have argued that the consequences of job insecurity as found among samples dominated by permanents cannot be generalised towards temporary employees. However, permanent employees may differ from contingent employees on other dimensions too, as for example weekly working hours. That is, future research may want to explore the consequences of job insecurity for those employed full-time versus part-time. Similarly, future research should explore the extent to which other stressors (e.g., low control) identified among a dominant full-time permanent population hold for contingent workers.

In general, an important area of future research should be to evaluate the extent to which the dominating standard of permanent, full-time employment can be generalised towards all types of employees. This runs counter to the bulk of contemporary research, which tends to generalise observations among traditional samples to all types of employees. Kluytmans and Ott (1999) refer to this research tradition as 'the psychology of lifetime employment'. However, along with the increased share of flexible workers (e.g., Guest, 2004; OECD, 2000), researchers should challenge this tradition. This might offer useful pathways to formulate a theoretical framework to interpret and explain the results as found in this study.

In this regard, the psychological contract might be a promising concept. The psychological contract is defined as the idiosyncratic set of reciprocal expectations held by employees concerning their obligations and their entitlements' (McLean Parks, Kidder \& Gallagher, 1998). Empirical studies found temporaries and permanents to hold different psychological contracts, along the distinction between transactional and relational psychological contract types (Van Dyne \& Ang, 1998; Coyle-Shapiro \& Kessler, 2002; Millward \& Brewerton, 1999; Millward \& Hopkins, 1998). The relational psychological contract involves open-ended agreements, with a focus on socioemotional exchanges as for example job security and loyalty. Transactional psychological contracts focus on economic exchange (e.g., pay for attendance).

The above might have important implications for the study of both temporary employment and job insecurity. First, this framework suggests temporaries and permanents to hold different expectations. These may reflect a standard against which the employment relationship is evaluated, due to their importance in predicting employees' attitudes, behavior and well-being (Anderson \& Schalk, 1998). That is, the impact of temporary employment cannot be assessed using the dominating standard related to permanent employment. Rather, temporary employment may challenge and transform the experience of work, resulting in new, but not necessarily inferior subjective work identities (Garsten, 1999).

Second, job security is defined as the protagonist of the relational psychological contract (Millward \& Brewerton, 2000). As a consequence, job insecurity represents a major violation of the relational psychological contract. The evaluation of psychological contract terms as either fulfilled or violated proved to yield intense attitudinal and emotional responses (Robinson \& Rousseau, 1994). In the case of job insecurity, this foremost affect those holding relational psychological contracts, as do permanents. Until now, this psychological contract perspective towards temporary employment and job insecurity is speculative. Nevertheless, future research may consider it a worthwhile avenue to pursue further.

\section{REFERENCES}

Abramis, D. (1994). Relationship of job stressors to job performance: linear or an inverted-U? Psychological Reports, 75 (1), 547-558.

Aiken, L. S. \& West, S. G. (1991). Multiple regression: Testing and interpreting interactions. Thousands Oaks, CA, US: Sage Publications.

Anderson, N. \& Schalk, R. (1998). The psychological contract in retrospect and prospect. Journal of Organizational Behavior, $19,637-647$. 
Aronsson, G., Gustafsson, K. \& Dallner, M. (2002). Work environment and health in different types of temporary jobs. European Journal of Work and Organizational Psychology, 11 (2), 151-175.

Baron, R. M. \& Kenny, D. A. (1986). The moderator-mediator variable distinction in social psychological research: Conceptual, strategic, and statistical considerations. Journal of Personality and Social Psychology, 51 (6), 1173-1182.

Beard, K. M. \& Edwards, J. R. (1995). Employees at risk: contingent work and the psychological experience of contingent workers. In C. I. Cooper \& D. M. Rousseau (Eds.), Trends in Organisational Behavior, Volume 2 (pp. 109-126). Oxford, England: John Willey \& Sons.

Benavides, F. G., Benach, J., Diez-Roux, A. V. \& Roman, C. (2000). How do types of employment relate to health indicators? Findings from the second European Survey on Working Conditions. Journal of Epidemiology and Community Health, 54, 494-501.

Benach, J., Gimeno, D. \& Benavides, F. G. (2002). Types of employment and health in the European Union. European Foundation for the Improvement of Living and Work Conditions, Office for official publications in the European Communities, Luxembourg.

Büssing, A. (1999). Can control at work and social support moderate psychological consequences of job insecurity? Results from a quasi experimental study in the steel industry. European Journal of Work and Organizational Psychology, 8, 219-242.

Casey, C. \& Alach, P. (2004). Just a temp? Women, temporary employment and lifestyle. Work, employment and society, (3), 459-480.

Connelly, C. E. \& Gallagher, D. G. (2004). Emerging trends in contingent work research. Journal of Management, 30 (6), 959-983.

Conway, N. \& Briner, R. B. (2002). Full-time versus part-time employees: Understanding the links between work status, the psychological contract, and attitudes. Journal of Vocational Behavior, 61 (2), 279-301.

Cook, J. \& Wall, T. (1980). New work attitude measures of trust, organizational commitment and personal need fulfilment. Journal of Occupational Psychology, 53 (1), 39-52.

Coyle-Shapiro, J. A. M. \& Kessler, I. (2000). Consequences of the psychological contract for the employment relationship: A large scale survey. Journal of Management Studies, 37 (7), 903-929.

De Cuyper, N., Isaksson, K. \& De Witte, H. (2005). Employment contracts and well-being among European workers. Ashgate.

De Witte, H. (2000). Arbeidsethos en jobonzekerheid: Meting en gevolgen voor welzijn, tevredenheid en inzet op het werk (Work ethic and job insecurity: Measurement and consequences for well-being, satisfaction and performance). In R. Bouwen, K. De Witte, H. De Witte \& T. Taillieu (Eds.), Van groep naar gemeenschap. Liber Amicorum Prof. Dr. Leo Lagrou (pp. 325-350). Leuven: Garant.

De Witte, H. (1999). Job insecurity and psychological well-being: Review of the literature and exploration of some unresolved issues. European Journal of Work and Organizational Psychology, 8 (2), 155-177

De Witte, H. \& Näswall, K. (2003). Objective versus subjective job insecurity: Consequences of temporary work for job satisfaction and organizational commitment in four European countries. Economic and Industrial Democracy, 24 (2), 149-188.

Galup, S., Saunders, C., Nelson, R. E. \& Cerveny, R. (1997). The use of temporary staff in a local government environment. Communication Research, 24, 698-730.

Garsten, C. (1999). Betwixt and between: Temporary employees as liminal subjects in flexibel organizations. Organization Studies, 20 (4), 601-617.

Geurts, S. (2000). SWING: Survey Work-home Interaction Nijmegen. Unpublished report. University of Nijmegen, Department of Work and Organizational Psychology
Guest, D. (2004). Flexible employment contracts, the psychological contract and employee outcomes: an analysis and review of the evidence. International Journal of Management reviews, 5/6(1), 1-19.

Guest, D. \& Conway, N. (2000). The psychological contract in the public sector. London: CIPD.

Guest, D. E. \& Conway, N. (1997). Employee motivation and the psychological contract. London: CIPD.

Isaksson, K., Bernhard, C., Claes, R., De Witte, H., Guest, D., Krausz, M., Peiro, J. M., Mohr, G. \& Schalk, R. (2003). Employment contracts and psychological contracts in Europe. Results from a Pilot study. SALTSA Report, 1.

Kinnunen, U. \& Nätti, J. (1994). Job insecurity in Finland: Antecedents and consequences. European Journal of Work and Organizational Psychology, 4 (3), 297-321.

Klandermans, B. \& Van Vuuren, T. (1999). Job insecurity: Introduction. European Journal of Work and Organizational Psychology, 8 (2), 145-153.

Kluytmans, F. \& Ott, M. (1999). Management of employability in the Netherlands. European Journal of Work and Organizational Psychology, 8 (2), 261-272

McDonald, D. J. \& Makin, P. J. (2000). The psychological contract, organizational commitment and job satisfaction of temporary staff. Leadership and Organizational Development Journal, 21, 84-91.

McLean Parks, J., Kidder, D. L. \& Gallagher, D. G. (1998). Fitting square pegs into round holes: Mapping the domain of contingent work arrangements onto the psychological contract. Journal of Organizational Behavior, 19 (Special issue), 697-730.

Millward, L. J. \& Brewerton, P. M. (2000). Psychological contracts: Employee relations for the twenty-first century? In C.L. Cooper \& I.T. Robertson (Eds), International Review of Industrial and Organizational Psychology (Vol. 15, pp.1-61). John Willey \& Sons.

Millward, L. J. \& Brewerton, P. M. (1999). Contractors and their psychological contract. British Journal of Management, 10, 253-274.

Millward, L. J. \& Hopkins, L. (1998). Psychological contracts, organizational and job commitment. Journal of Applied Social Psychology, 28 (16), 1530-1556.

Mohr, G. \& Rigotti, T. (2003). Irritation (Gereiztheit). In A. Glöckner-Rist (Ed.), ZUMA-informationssystem. Elektronisches Handbuch Sozialwissenschaftlicher Erhebungsinstrumente. Version 7.00. Mannheim: Zentrum für Umfragen, Methoden \& Analyses.

Näswall, K. \& De Witte, H. (2003). Who feels insecure in Europe? Predicting job insecurity from background variables. Economic and Industrial Democracy, 24 (2),189-215

OECD. (2002). Employment outlook. Paris: Organization for Economic Co-operation and Development.

Paoli, P. \& Merllié, D. (2002). Third European survey on working conditions. European Foundation for the Improvement of Living and Work Conditions, Office for official publications in the European Communities, Luxembourg.

Parker, S.K., Griffin, M.A., Sprigg, C.A. \& Wall, T.A. (2002). Effect of temporary contracts on perceived work characteristics and job strain: A longitudinal study. Personnel Psychology, 55, 689-717.

Pearce, J. (1993). Toward an organizational behavior of contract laborers: Their psychological involvement and effects on employee co-workers. Academy of Management Journal, 36 (5):1082-1096.

Price, J. (1997). Handbook of organizational measurement. International Journal of Manpower, 18 (4/5/6), 301-558.

Rigotti, T., Mohr, G., De Cuyper, N., De Witte, H., Bernhard, C., Isaksson, K., de Jong, J., Schalk, R., Caballer, A., Gracia, F., Peiró, J.M., Ramos, J., Clinton, M., Guest, D., Krausz, M. \& Staynvarts, N. (2003). Instruction work and blue print for methodology. Unpublished research report. Leipzig: Germany. 
Robinson, S. L. \& Rousseau, D. M. (1994). Violating the psychological contract: Not the exception but the norm. Journal of Organizational Behavior, 15, 245-229.

Schaufeli, W. \& Bakker, A. (2003). UWES. Utrecht Work Engagement Scale. Unpublished Report. Occupational Health Psychology Unit, Utrect University. Utrecht: The Netherlands.

Sverke, M., Gallagher, D. G. \& Hellgren, J. (2000). Alternative work arrangments: Job stress, well-being, and work attitudes among employees with different employment contracts. In K. Isaksson, L. Hogstedt, C. Eriksson \& T. Theorell (Eds.), Health effects of the new labour market. New York: Plenum.

Sverke, M., Hellgren, J., Näswall, K., Chirumbolo, A., De Witte, H. \& Goslinga, S. (2004). Job insecurity and union membership. European Unions in the wake of flexible production. Work and Society, 42. Brussels: Peter Lang.
Sverke, M., Hellgren, J. \& Näswall, K.(2002). No Security: A meta-analysis and review of job insecurity and its consequences. Journal of Occupational Health Psychology, 7 (3), 242-264.

Van Breukelen, W. \& Allegro, J. (2000). Effecten van een nieuwe vorm van flexibilisering van de arbeid (Effects of a new form of labour flexibility). Gedrag en Organisatie, 13 (2), 107-124.

Van Dyne, L. \& Ang, S. (1998), Organizational citizenship behavior of contingent workers in Singapore. Academy of Management Journal, 41 (6): 692-703.

Virtanen, J., Vahtera, M., Kivimäki, J., Pentii, J. \& Ferrie, J. (2002). Employment security and health. Journal of Epidemiological Community Health, 56, 569-574.

Ware, J. E. (1999). SF-36 Health Survey. In M. E. Maruish (Ed), The use of psychological testing for treatment planning and outcomes assessment (2nd edition) (pp. 1227-1246). Mahwah, NJ, US: Lawrence Erlbaum Associates. 